\title{
The Seedcoat Color Genotype of 'Prim' and the Manteca and Coscorrón Market Classes of Common Bean
}

\author{
Mark J. Bassett ${ }^{1}$ \\ Horticultural Sciences Department, Institute of Food and Agricultural Sciences, \\ University of Florida, Gainesville, FL 32611-0690 \\ Additional index words. Phaseolus vulgaris, inheritance
}

\begin{abstract}
Anecdotal evidence exists for nonflatulence among Chilean Manteca and Coscorrón market classes of common bean (Phaseolus vulgaris L.), and there is an hypothesis that the seedcoat color may be associated with superior digestibility. The inheritance of seedcoat color in 'Prim', a Manteca market-class dry bean, was investigated using a protocol employing genetic interpretation of seedcoat colors in the $F_{1}$ from testcrosses of 'Prim' with a series of tester stocks. Most of the genetic tester stocks were constructed previously by backcrossing selected recessive alleles for seedcoat color into a recurrent parent (5-593) with seedcoat color genotype $P[C r] D J G B V R k A s p$. The genetic tester stocks included two varieties, 'Masterpiece' and 'V0687', and testers constructed on the 5-593 background, viz., $j \mathrm{BC}_{2}$ 5-593, $d j \mathrm{BC}_{2}$ 5-593, asp $\mathrm{BC}_{2}$ 5-593, $b$ v $\mathrm{BC}_{2}$ 5-593, $v \mathrm{BC}_{2}$ 5-593, and $c^{\mathrm{u}} \mathrm{BC}_{3}$ 5-593. The seedcoat color genotype of 'Prim' was found to be $P[C r] d$ $j G b v^{\text {lae }}$. The implications of this genotype for pigment chemistry are discussed.
\end{abstract}

In Chile there are two market classes of common beans, Mantecas (pale lemon-yellow seedcoats) and Coscorróns (pale lemon-yellow/white mottled or striped seedcoats), which are considered "beans for the rich man's table" because they are reportedly nonflatulent and more expensive to grow (Leakey, 1992). Leakey (1992) hypothesized that the genes controlling seedcoat color in Mantecas and Coscorróns may concomitantly control the reduction of flatulence, but testing the validity of his hypothesis is beyond the scope of this paper. Leakey (1992) proposed that the seedcoat color genotype of Mantecas is $P C d$ $j g b v$ and that Coscorróns have the same genotype except for an allele at $C$ that controls pattern (mottled or striped).

Leakey (1992) has conducted a breeding program to produce new varieties with the Manteca seedcoat color, but with determinate habit and early flowering. One variety released from this program is 'Prim' (Leakey, personal communication). Beninger et al. (1998) studied the seedcoat pigment chemistry of 'Prim' and found two flavonol glycosides: 1) kaempferol-3- $O-\beta$-D-glucoside and 2) kaempferol-3-O- $\beta$-D-glucopyranosyl $(2 \rightarrow 1)-O-\beta$-D-xylopyranoside. Feenstra (1960) found the same two compounds in seedcoats with genotype $P C d j g b v^{\text {lae }} R k$.

Received for publication 29 June 1998. Accepted for publication 22 Sept. 1998. Florida Agricultural Experiment Station Journal Series no. R-06400. The cost of publishing this paper was defrayed in part by the payment of page charges. Under postal regulations, this paper therefore must be hereby marked advertisement solely to indicate this fact.

${ }^{1}$ Professor.
The objectives of this work were to determine the seedcoat color genotype of 'Prim' and to relate the results to previous findings.

\section{Materials and Methods}

In 1985, a program was initiated to develop genetic tester stocks, each with one or more recessive marker genes for seedcoat color or pattern backcrossed into the recurrent parent, Florida dry bean breeding line 5-593. Details of the backcross procedure are described elsewhere (Bassett, 1994). Line 5-593 has a determinate habit, purple flowers, and shiny, black seedcoats. The seedcoat genotype of 5-593 is Stp $T Z l^{+}$Bip $P[C r] D J G B V R k$, which includes genes for seedcoat pattern, partly colored patterns, and color (Bassett, 1998). Line 5-593 also carries the shiny seedcoat gene Asp (Bassett, 1996a). Genetic stocks that were developed by backcrossing a marker gene to the 5-593 recurrent parent are designated: gene symbol $\mathrm{BC}_{\mathrm{n}}$ 5-593. For example, $v \mathrm{BC}_{3} 5-593$ indicates that the $v$ allele is in backcross three to 5-593.

The genetic tester stocks and varieties with established seedcoat color genotypes that were used as testcross parents with 'Prim' are listed and described in Table 1. The testcross parents $\mathrm{P}_{2}$ through $\mathrm{P}_{9}$ were crossed with 'Prim' $\left(\mathrm{P}_{1}\right)$ in Fall 1992 in the greenhouse. The $F_{1}$ progenies of the testcrosses were grown in the greenhouse in Winter 1993, and descriptive data were taken on flower color and the pattern and color of the seedcoats of the $F_{1}$ plants.

\section{Results and Discussion}

The phenotypes of the seedcoats of the testcross $F_{1}$ plants are described in Table 2 . Using the phenotypes of $F_{1}$ progeny from testcrosses with special genetic test stocks was first proposed by Bassett (1992). The genetic stocks have only specified recessive alleles substituted into a genetic background having all dominant alleles at the other seedcoat color loci. The presence of the dominant alleles suppresses the complex interactions that unwanted recessive alleles would otherwise have on the expression of the selected recessive alleles for seedcoat color. In theory, the testcross should lead to only one of two results: 1) an allelic response where seed of the $F_{1}$ plants have the same phenotype as the genetic tester or 2) a nonallelic response.

The testcross of 'Prim' with $\mathrm{P}_{2}$ gave an allelic response, except for the mottling (Table 2). The result indicates that 'Prim' carries the "test allele" $j$. However, the mottling may be due to 'Prim' carrying an allele at $C$ that has some of the attributes of the dominant unpatterned $C$ allele and some attributes of the standard recessive allele $c$ as described by Prakken (1970). The subtle mottling is produced by the heterozygote $C / c$, but the allele at $C$ carried by 'Prim' does not have all the attributes of standard $c$. The contrary evidence

Table 1. The seedcoat phenotypes and genotypes of 'Prim' and the stocks used in testcrosses to determine the seedcoat genotype of 'Prim'.

\begin{tabular}{|c|c|c|c|c|}
\hline \multirow{2}{*}{$\begin{array}{l}\text { Parent } \\
\text { no. }\end{array}$} & \multirow{2}{*}{$\begin{array}{l}\text { Stock } \\
\text { name }\end{array}$} & \multicolumn{2}{|c|}{ Seedcoat color } & \multirow[b]{2}{*}{ Reference $^{\mathrm{z}}$} \\
\hline & & Phenotype & Genotype & \\
\hline$\overline{P_{1}}$ & Prim & $\begin{array}{l}\text { Yellowish white } \\
\text { with pale purple corona }\end{array}$ & $P C d j G b v^{\text {lae }} A s p$ & \\
\hline $\mathrm{P}_{2}$ & $j \mathrm{BC}_{2} 5-593$ & $\begin{array}{l}\text { Dull dark purple } \\
\text { with margo pattern }\end{array}$ & $P C D j G B V A s p$ & Bassett, 1996a \\
\hline $\mathrm{P}_{3}$ & $d j \mathrm{BC}_{2} 5-593$ & $\begin{array}{l}\text { Dull dark purple } \\
\text { with white hilum ring }\end{array}$ & $P C d j G B V A s p$ & Bassett, 1996a \\
\hline $\mathrm{P}_{4}$ & asp $\mathrm{BC}_{2} 5-593$ & Dull black & $P C D J G B V a s p$ & Bassett, 1996a \\
\hline $\mathrm{P}_{5}$ & $b v \mathrm{BC}_{2} 5-593$ & Yellow brown & $P C D J G b v A s p$ & Bassett, 1995a \\
\hline $\mathrm{P}_{6}$ & Masterpiece & $\begin{array}{l}\text { Pale beige to greenish- } \\
\text { yellow with purple corona }\end{array}$ & $P C J g b v^{1 \mathrm{ae}} A s p$ & Nakayama, 1961 \\
\hline $\mathrm{P}_{7}$ & V0687 & Light red kidney & $P c^{\mathrm{u}} J g b v^{\text {lae }} r k A s p$ & Lamprecht, $1961^{\mathrm{y}}$ \\
\hline $\mathrm{P}_{8}$ & $v \mathrm{BC}_{2} 5-593$ & Mineral brown & $P C D J G B v A s p$ & Bassett, 1995b \\
\hline $\mathrm{P}_{9}$ & $c^{\mathrm{u}} \mathrm{BC}_{3} 5-593$ & Cartridge buff & $P c^{\mathrm{u}} D J G B V A s p$ & Bassett, 1996a \\
\hline
\end{tabular}

${ }^{2}$ The references cited provide the supporting evidence for the seedcoat color genotype listed for each parental stock.

yThe work of Lamprecht (1961) only gives $c$ and $v$, but Bassett (unpublished data) has determined that V0687 carries $c^{\mathrm{u}}$ by means of an allelism test with $\mathrm{P}_{9}$ and $v^{\text {lae }}$ by means of an allelism test with $\mathrm{P}_{5}$ 
Table 2. Results of testcrosses between 'Prim' and a series of genetic stocks and varieties with known seedcoat genotypes.

\begin{tabular}{ll}
\hline \hline Testcross & \multicolumn{1}{c}{ Phenotype of seedcoats of seeds on $\mathrm{F}_{1}$ plants from the testcross } \\
\hline $\mathrm{P}_{1} \times \mathrm{P}_{2}$ & $\begin{array}{c}\text { Typical margo pattern produced by } j \text {, pale corona and black hilum ring, but mottling } \\
\text { in dark greenish purple/gray buff. } \\
\mathrm{P}_{1} \times \mathrm{P}_{3}\end{array}$ \\
$\begin{array}{c}\text { Margo pattern with colorless hilum ring and corona; color highly variable from brown } \\
\text { to purple }\end{array}$ \\
$\mathrm{P}_{1} \times \mathrm{P}_{4}$ & $\begin{array}{l}\text { Shiny unpatterned black } \\
\mathrm{P}_{1} \times \mathrm{P}_{5}\end{array}$ \\
$\mathrm{P}_{1} \times \mathrm{P}_{6}$ & Yellow-brown with purple corona \\
$\mathrm{P}_{1} \times \mathrm{P}_{7}$ & Yellow-brown with purple corona \\
$\mathrm{P}_{1} \times \mathrm{P}_{8}$ & Yellow-brown/cartridge buff marbling with patterned purple corona \\
$\mathrm{P}_{1} \times \mathrm{P}_{9}$ & Subtle mottling with mineral brown/pale brown; highly variable from seed to seed. \\
\hline
\end{tabular}

is presented below from the results of other testcrosses. The testcross of 'Prim' with $\mathrm{P}_{3}$ gave an allelic response with no complications (Table 2), and indicates that 'Prim' carries the genotype $d j$.

The asper gene (asp) is the common and widely distributed gene for dull seedcoats and, unlike $j$, has no effect on seedcoat color. 'Prim' has a dull seedcoat due to $j$, and only a testcross with the $a s p$ tester can determine whether $a s p$ may be carried cryptically by 'Prim'. The testcross of 'Prim' with $\mathrm{P}_{4}$ gave a nonallelic response (Table 2), which indicates that 'Prim' carries Asp.

The testcross of 'Prim' with $\mathrm{P}_{5}$, the yellowbrown tester, gave an allelic response, except that the $F_{1}$ had purple corona due to genotype $v^{\text {lae }} / v$ (Table 2) (Bassett, 1995b). 'Prim' has the pink flower color and purple corona that are pleiotropic effects of the $v^{\text {lae }}$ allele at $V$ (Bassett, 1995b). That result is interpreted to mean that 'Prim' carries $b v^{\text {lae }}$. Also, the failure of the $\mathrm{F}_{1}$ with $\mathrm{P}_{5}$ to express either an unpatterned or mottled dominant red color indicates that 'Prim' must carry the $r$ allele for dominant red color in the complex $C$ locus.

The testcross of 'Prim' with $\mathrm{P}_{6}$ (with $g b$ $\left.v^{\text {lae }}\right)$ permits a test for the genotype of 'Prim' at $G$. The testcross result was yellow-brown with purple corona (Table 2), which is a nonallelic response at $G$. That result indicates that 'Prim' carries $G$. The testcross of 'Prim' with $\mathrm{P}_{7}$ (with $g b v)$ gave yellow-brown/cartridge buff marbling with a patterned purple corona (Table 2). The purple in the corona was also marbled with cartridge buff. The yellow-brown color is produced by allelism at $b$ and $v^{\text {lae }}$ in 'Prim', but the marbling is an interaction of the $c^{\mathrm{u}}$ in V0687 with the allele at $C$ in 'Prim'. The latter interpretation was tested directly in the testcross with $\mathrm{P}_{9}$ discussed below. The yellowbrown color also is a nonallelic interaction with the $G$ in 'Prim'.

The above results are consistent with the hypothesis that 'Prim' has the genotype $G b$ $v^{\text {lae }}$, and are not consistent with the hypothesis of Leakey (1992) that 'Prim' carries $g$.

The testcross of 'Prim' with $\mathrm{P}_{8}$ gave $\mathrm{F}_{1}$ plants having seedcoats with subtle mottling of mineral brown/pale brown (Table 2). The allelism at $v$ already is established and needs no further comment, but the appearance of mottling is usually interpreted as an expression of the heterozygous genotype $\mathrm{Clc}$ (Prakken, 1970). Extensive observation of $F_{2}$ progeny from the testcross grown in the field and greenhouse failed to produce the expected true breeding $c / c$ genotype with pale brown seedcoats (data not shown). In a previous paper, Bassett (1996b) described 'Prim' as carrying $\left[\begin{array}{ll}c & r\end{array}\right]$ to account for the apparent heterozygous $C / c$ mottling described above, but, as will be shown below, the allele at the $C$ locus in 'Prim' does not adequately meet other criteria for being defined as a recessive $c$.

The testcross of 'Prim' with $\mathrm{P}_{9}$ gave a nonallelic response, viz., black/cartridge buff marbling (Table 2). In unpublished work by the author, the original source ('Wachs Digoin') of the standard recessive $c$ allele (Prakken, 1970) was testcrossed with $P_{9}$, and the $F_{1}$ produced seed that were brown tinged with grayish-indigo. Thus, the allele at the $C$ locus in 'Prim' cannot be the same allele as that in 'Wachs Digoin', and neither is it the $c^{\mathrm{u}}$ allele. 'Prim' must carry a dominant allele at $C$ that is not the same as the dominant allele in 5-593. Therefore, the chromosome region of the $C$ locus of 'Prim' must carry $[C r]$, where the brackets indicate the virtually unbreakable linkage between the $C$ and $R$ genes in what Prakken (1970) calls "the complex $C$ locus."

Combining all the above testcross results, I conclude that the seedcoat color genotype of 'Prim' is $P[C r] d j G b v^{\text {lae }}$ with $A s p$ carried cryptically, which Beninger et al. (1998) found to produce two flavonol glycosides: 1) kaempferol-3-O- $\beta$-D-glucoside and 2 ) kaempferol-3-O- $\beta$-D-glucopyranosyl $(2 \rightarrow 1)$ $O-\beta$-D-xylopyranoside. Feenstra (1960) found the same two flavonol glycosides produced by the genotype $P C d j g b v^{\text {lae }}$, which differs from the genotype of 'Prim' only by the substitution of $g$ for the $G$ of 'Prim'. In the presence of $j$ (and especially with $d j$ ) the yellow pigment produced by $G b v$ (or $G b v^{\text {lae }}$ ) is greatly reduced.

When the same laboratory procedures (as with 'Prim'; Beninger et al., 1998) were used to analyze flavonoid compounds in seedcoats of three genetic tester stocks- $P C J G B v \mathrm{BC}_{3}$ 5-593, $P C J G b v \mathrm{BC}_{3}$ 5-593, and $P C J g b v$
$\mathrm{BC}_{3}$ 5-593 - the only kaempferol compound detected in any appreciable quantity was kaempferol-3- $O$ - $\beta$-D-glucoside (astragalin) (Beninger et al., unpublished data). Unexpectedly, the quantity of astragalin (a yellow pigment) was about twice as great in $P C J g b v$ $\mathrm{BC}_{3}$ 5-593 as in $P C J G b v \mathrm{BC}_{3}$ 5-593, where the former genetic tester stock is a pale greenish-yellow and the latter stock a much stronger yellow-brown. The current hypothesis under investigation by Beninger et al. is that tannins may play a much more important role than flavonoids in producing the visible colors in genetic stocks with genotype $P C J v$ (includes all gene combinations at $G$ and $B)$.

\section{Literature Cited}

Bassett, M.J. 1992. Development of a protocol for determining the genotype of seedcoat color and color pattern in common bean. Annu. Rpt. Bean Improv. Coop. 35:191-192.

Bassett, M.J. 1994. The griseoalbus (gray-white) seedcoat color is controlled by an allele ( $\left.p^{\text {gri }}\right)$ at the $P$ locus in common bean. HortScience 29:1178-1179.

Bassett, M.J. 1995a. A new recessive allele at the $C$ locus for seedcoat color in common bean. J. Amer. Soc. Hort. Sci. 120:896-899.

Bassett, M.J. 1995b. The dark corona character in seedcoats of common bean cosegregates with the pink flower allele $v^{\text {lae }}$. J. Amer. Soc. Hort. Sci. 120:520-522.

Bassett, M.J. 1996a. The margo (mar) seedcoat color gene is a synonym for the Joker ( $j$ ) locus in common bean. J. Amer. Soc. Hort. Sci. 121:1028-1031.

Bassett, M.J. 1996b. A complex $C$ region genotype $[? R]$ that with $G B v^{\text {lae }}$ produces dark seal-brown seedcoat color in common bean. J. Amer. Soc. Hort. Sci. 121:594-598.

Bassett, M.J. 1998. The genotype for seedcoat color and pattern of breeding line 5-593, 1998. Annu. Rpt. Bean Improv. Coop. 35:191-192.

Beninger, C.W., G.L. Hosfield, and M.G. Nair. 1998. Flavonol glycosides from the seedcoat of a new Manteca-type dry bean (Phaseolus vulgaris L.). J. Agr. Food Chem. 46:2906-2910.

Feenstra, W.J. 1960. Biochemical aspects of seedcoat colour inheritance in Phaseolus vulgaris L. Meded. Landbouwhogeschool Wageningen 602:1-53.

Lamprecht. H. 1961. Die Vererbung der rezessiv roten Testabarbe von Phaseolus, sowie Bemerkungen zur Manifestation und Symbolik von Testafarbgenen. Agr. Hort. Genet. 19:344-359.

Leakey, C.L.A. 1992. Breeding on the $C$ and $J$ and $B$ loci for modification of bean seedcoat flavonoids with the objective of improving food acceptability. Annu. Rpt. Bean Improv. Coop. 35:xiii-xvii.

Nakayama, R. 1961. Genetical studies on kidney beans (Phaseolus vulgaris L.). VI. Genetical behavior of plant color, with special reference to seed-coat color in the hybrids between White Kidney and other varieties. Bul. Fac. Agr. Hirosaki Univ. 7:37-65.

Prakken, R. 1970. Inheritance of colour in Phaseolus vulgaris L. II. Critical review. Meded. Landbouwhogeschool Wageningen 70-23:1-38. 